\title{
Nesting Activity of Kittlitz's Murrelet in the Kakagrak Hills, Northwestern Alaska
}

\author{
Michelle L. Kissling ${ }^{1,2}$ and Stephen B. Lewis ${ }^{1}$
}

(Received 22 January 2015; accepted in revised form 10 May 2016)

\begin{abstract}
The Kittlitz's Murrelet (Brachyramphus brevirostris) is a broadly distributed but uncommon seabird species endemic to coastal Alaska and eastern Russia. Although northern Alaska constitutes a large portion of this species' range, little is known about Kittlitz's Murrelets in this vast region. We studied nesting activity of Kittlitz's Murrelets in the Kakagrak Hills, Cape Krusenstern National Monument, in northern Alaska during summer 2014. Between 15 and 26 June, we located two active Kittlitz's Murrelet nests by walking line transects in 28 sampling blocks $(250 \times 250 \mathrm{~m})$ that were stratified by two habitat types (Alpine Alkaline Barrens and Alpine Dryas Dwarf Shrub) and selected randomly. We found one additional active nest opportunistically while walking between blocks. All three nests were located in Alpine Alkaline Barrens habitat, and all failed during the egg stage. Causes of failure were nest abandonment $(\mathrm{n}=1)$, depredation $(\mathrm{n}=1)$, and unknown $(\mathrm{n}=1)$. Overall mean nest density was 0.80 nests $/ \mathrm{km}^{2}(\mathrm{SE}=0.52)$. Although our sample of nests was small, our results demonstrate that Kittlitz's Murrelets nest regularly in northern Alaska. However, the apparently low productivity raises questions about the reproductive value of this region to this cryptic and secretive species.
\end{abstract}

Key words: Kittlitz's Murrelet; Brachyramphus brevirostris; Alaska; nesting habitat; nest density; nesting success; sampling design

RÉSUMÉ. Le guillemot de Kittlitz (Brachyramphus brevirostris) est une espèce d'oiseau marin largement répandue, mais rare, endémique aux zones côtières de l'Alaska et de l'est de la Russie. Même si le nord de l'Alaska représente une grande portion de l'aire de répartition de cette espèce, nous en savons très peu sur les guillemots de Kittlitz dans cette vaste région. Au cours de l'été 2014, nous avons étudié l'activité de nidification du guillemot de Kittlitz dans les collines Kakagrak, au Cape Krusenstern National Monument, dans le nord de l'Alaska. Du 15 au 26 juin, nous avons repéré deux nids actifs du guillemot de Kittlitz en marchant dans les transects linéaires de 28 blocs d'échantillonnage $(250$ × $250 \mathrm{~m})$ composés de deux types d'habitat (la toundra alpine alcaline et l'arbuste nain alpin Dryas) sélectionnés au hasard. Nous avons trouvé un autre nid actif de façon opportuniste en marchant entre les blocs. Les trois nids étaient situés dans la toundra alpine alcaline et ils ont tous échoué au stade de l'œuf. Les causes de l'échec étaient l'abandon du nid $(n=1)$, la déprédation $(n=1)$ et une cause inconnue $(\mathrm{n}=1)$. La moyenne générale de la densité des nids était de $0,80 \mathrm{nid} / \mathrm{km}^{2}$ (écart-type de 0,52 ). Même si notre échantillonnage de nids était petit, nos résultats montrent que le guillemot de Kittlitz niche régulièrement dans le nord de l'Alaska. Cependant, le faible taux de réussite apparent soulève des questions quant à la valeur reproductive de cette région pour cette espèce cryptique et discrète.

Mots clés : guillemot de Kittlitz; Brachyramphus brevirostris; Alaska; habitat de nidification; densité des nids; réussite de nidification; plan d'échantillonnage

Traduit pour la revue Arctic par Nicole Giguère.

\section{INTRODUCTION}

The Kittlitz's Murrelet (Brachyramphus brevirostris) is a broadly distributed but uncommon seabird that occupies most of coastal Alaska and eastern Russia throughout its annual cycle. During the breeding season, this species typically is associated with glacially influenced marine waters (e.g., near tidewater glaciers) in south-coastal Alaska, where most (66\%) of the global population is found (USFWS, 2013). Low numbers of the species also inhabit coastal waters with little or no direct glacial influence near the Aleutian Islands (Madison et al., 2011), northern Alaska
(Day et al., 2011), and eastern Russia (Artukhin et al., 2011). In a few areas of south-coastal Alaska (e.g., Prince William Sound, Glacier Bay; Kuletz et al., 2011; Piatt et al., 2011; but see also Kirchhoff et al., 2014), populations of Kittlitz's Murrelets may have declined substantially during the 1990s, but most appear to have stabilized at lower population levels since then (USFWS, 2013; except for Icy Bay, see Kissling et al., 2015a, b). The cause of the apparent declines or recent stabilizations is not known, but poor productivity has been proposed as a demographic bottleneck (Day and Nigro, 2004; USFWS, 2013; Kissling et al., 2015b).

\footnotetext{
${ }^{1} 947$ Goldbelt Avenue, Juneau, Alaska 99801, USA

${ }^{2}$ Corresponding author: michelle_kissling@yahoo.com

(C) The Arctic Institute of North America
} 
Unlike most seabird species, Kittlitz's Murrelets do not nest in colonies, but instead nest solitarily at low densities. They lay a clutch of one egg on the ground or a cliff ledge and rely on their cryptic plumage and secretive behaviors to avoid detection by predators (Day et al., 1999). Not surprisingly, few nest records exist $(\mathrm{n}=234$ nests rangewide as of January 2013; USFWS, 2013); most of these nests were recorded only recently, and nearly all (88\%) were found during targeted studies on the nesting ecology of this species in south-coastal Alaska. All of these studies have reported low, but variable, apparent nesting success (mean $=0.16-0.50$ ), with the most common causes of failure being predation, starvation, and exposure of the egg or chick (Kaler et al., 2009; Lawonn, 2012; Kissling et al., 2015b; summarized in USFWS, 2013).

Compared with south-coastal and southwestern Alaska, little is known about Kittlitz's Murrelets in northern Alaska, even though this region constitutes a large portion of this species' range and potential nesting habitat (Felis et al., in press). During the breeding season, the Kittlitz's Murrelet population in northern Alaska is estimated to be $\sim 500$ birds, but this estimate increases to $\sim 9000$ birds during the postbreeding season (Day et al., 2011), when birds from southcoastal Alaska migrate to the Chukchi and Beaufort Seas. Between 1904 and 2013, only 13 nests were found in northern Alaska; nine nests were found in the egg stage and two in the chick stage, and nest stage at the remaining two nests was unknown (Felis et al., in press). None of these nests were monitored to determine nest fate. Thus, even though active nests of the Kittlitz's Murrelet have been found in northern Alaska, successful reproduction of this species in this vast area has not yet been documented.

On 15 June 2010 and 16 June 2013, visitors opportunistically located two active Kittlitz's Murrelet nests in the Kakagrak Hills, Cape Krusenstern National Monument, in northwestern Alaska (see description of the 2010 nest in Day et al., 2011). Both of these nests were found in the egg stage, and neither one was monitored for more than six days. We explored these discoveries further by studying nesting activity of Kittlitz's Murrelets in the Kakagrak Hills, Cape Krusenstern National Monument, in northwestern Alaska, in June-August 2014. Specifically, our goals were (1) to generate unbiased estimates of nest density and nesting success and (2) to identify factors influencing nest fate.

\section{STUDY AREA}

We conducted our study in the Kakagrak Hills $\left(67.295^{\circ} \mathrm{N},-163.660^{\circ} \mathrm{W}\right)$, which lie $\sim 80 \mathrm{~km}$ north of the village of Kotzebue, Alaska, and within the Cape Krusenstern National Monument (Fig. 1). The study area was small $\left(\sim 40 \mathrm{~km}^{2}\right)$ and discrete, with natural boundaries of the Tasaychek Lagoon and Chukchi Sea to the west, the Kilikmak Creek to the north and east, and the Tasaychek Creek to the south. Elevation ranged from $0 \mathrm{~m}$ (sea level) to
$284 \mathrm{~m}$ (Naglatuk Hill), and distance from the ocean ranged from $0 \mathrm{~km}$ (mean high tide) to $10 \mathrm{~km}$. The marine waters adjacent to the study area were generally shallow, with weak currents and high freshwater input from the Noatak and Kobuk Rivers to the southeast.

The study area included five types of physiography (alpine, upland, lowland, riverine, and coastal) and consisted primarily of four categories of vegetation, as well as barren land (Jorgenson et al., 2009). Dominant vegetation was Dryas Dwarf Shrub and Sedge-Dryas Meadow, followed by Dwarf Birch-Tussock Shrub and Dwarf BirchEricaceous-Willow Low Shrub (see Jorgenson et al., 2009 for full descriptions). Sites that were not on an active floodplain and where the total vascular plant cover was less than $30 \%$ were considered barren land.

Between 1 June and 31 August 2014, the average temperature in Kotzebue was $11.3^{\circ} \mathrm{C}$ and total precipitation was $11.4 \mathrm{~cm}$ (National Weather Service, 2014). Average wind speed was $18.2 \mathrm{~km} / \mathrm{h}$ (range: 8.2 to $36.2 \mathrm{~km} / \mathrm{h}$ ).

\section{METHODS}

As part of a reconnaissance trip to the study area in late August 2013, we visited both nests that were found in 2010 and 2013. At the 2010 nest, we carefully excavated the nest cup and found no indication that the nest had previously contained an egg or nestling (i.e., no fecal matter, down or feathers, or eggshell fragments). We concluded that this nest had probably failed during incubation. We also found no evidence of its use since 2010. At the 2013 nest, we found a broken egg with roughly two-thirds of the eggshell still intact, but no fecal matter, down, or feathers. We concluded that this nest also had failed during incubation. During the same trip, we opportunistically found two possible nest cups that resembled known nests (following Kenney and Kaler, 2013). We used these two known and two possible nests to inform our sampling design.

We surveyed for Kittlitz's Murrelet nests between 15 and 26 June 2014, using a stratified random sampling design with ecotype as the stratification layer. We chose this time period to coincide with dates of previous nest discoveries and estimated murrelet phenology in northern Alaska (Day, 1996). We overlaid a grid of $250 \times 250 \mathrm{~m}$ blocks across our study area and assigned each block to an ecotype, namely the ecotype that covered the majority of area within the block, by using ArcGIS 10.1 (ESRI, Inc., Redlands, California). We sampled 28 blocks, including the four blocks that contained known or possible nests. The 2010 nest was located in Alpine Dryas Dwarf Shrub ecotype, and the 2013 nest and two possible nests were found in Alpine Alkaline Barrens ecotype. We then randomly selected the 24 remaining blocks with a weighted sampling allocation of $80 \%$ Alpine Alkaline Barrens and 20\% Alpine Dryas Dwarf Shrub.

Two observers searched each block for Kittlitz's Murrelet nests by walking nine transects spaced $25 \mathrm{~m}$ apart 


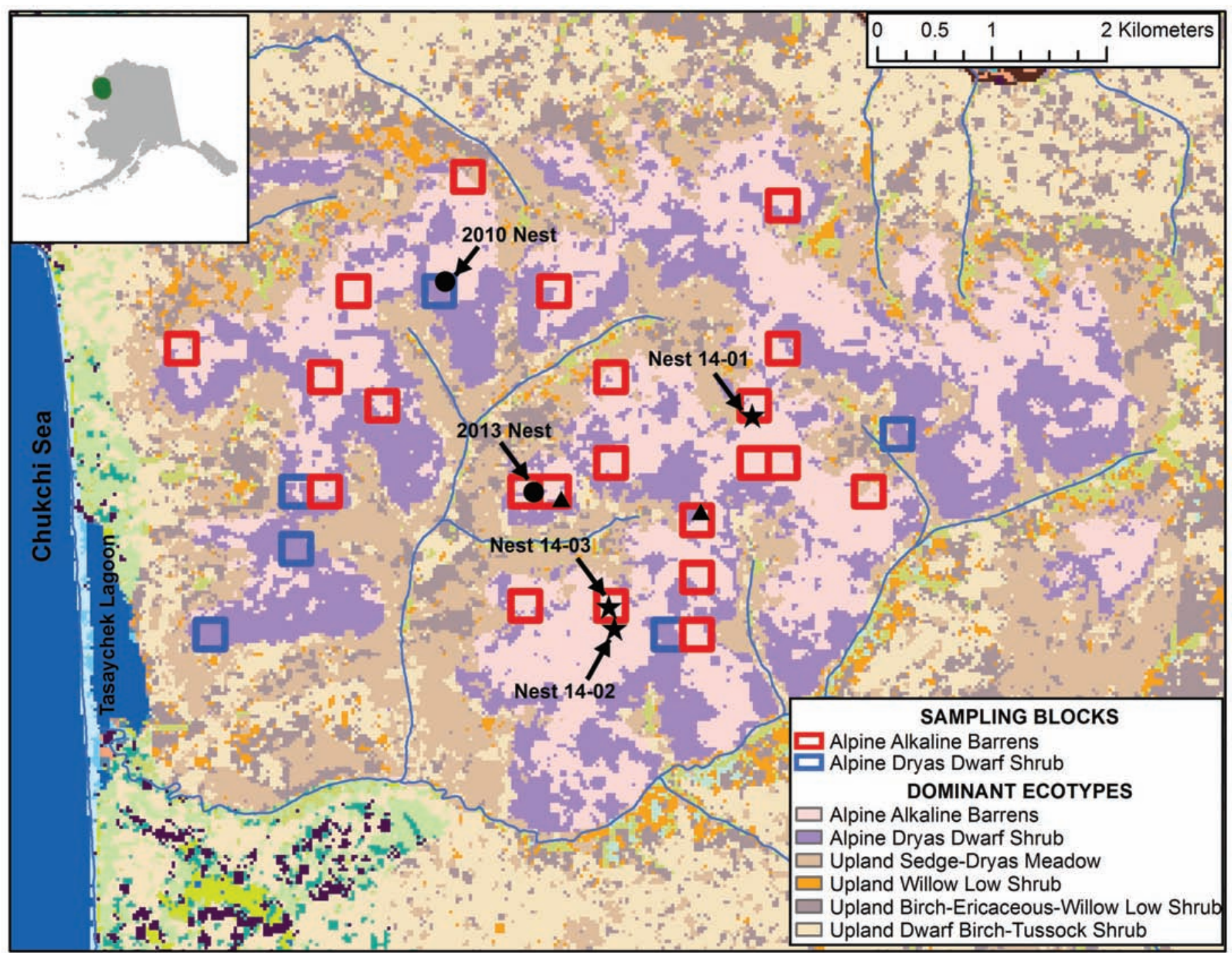

FIG. 1. Map showing location of Cape Krusenstern National Monument, northwestern Alaska (inset), and the Kakagrak Hills study area. Sampling blocks are identified by ecotype (see Jorgenson et al., 2009 for full descriptions of ecotypes). Stars represent the nests found and monitored during our study in summer 2014. Also shown are known nests (circles) and possible nests (triangles) found in previous years.

within the block and all four of its borders. Observers walked in the same direction and at the same pace to assist one another in the event of flushing a bird. For each block, we recorded date, start and stop times, elevation (m) at each corner, transect orientation, and bird and mammal activity near or within the block. Alpine Alkaline Barrens blocks averaged $159 \mathrm{~m}$ in elevation and $4.7 \mathrm{~km}$ from the ocean, compared to $117 \mathrm{~m}$ and $4.1 \mathrm{~km}$ for Alpine Dryas Dwarf Shrub. Our average time to sample one block was 89 minutes (range $=49-204 \mathrm{~min}$ ).

When we discovered an active Kittlitz's Murrelet nest (i.e., a nest with an egg, an incubating adult, or both), we stopped searching immediately and attended to the nest. We covered the exposed egg with a piece of cloth or hat and put on latex gloves to help avoid nest detection by predators. We recorded geographic coordinates, time of discovery, distance (m) from observer to nest when the incubating adult was flushed, and the direction the adult flushed. We measured egg length and width $(\mathrm{mm})$ and weight $(\mathrm{g})$ and floated the egg to estimate the stage of development (Kaler et al., 2008). We then placed a remote camera system (Hyperfire PC900, Reconyx, Inc., Holmen, Wisconsin) roughly 2-5 m from the nest, aiming it downhill and away from direct sun or weather. We programmed the camera to take one photograph every 60 seconds. We spent less than 30 minutes at each nest following its discovery and left the nest area immediately after gathering data and deploying the camera. We then finished surveying the remainder of the block.

Between 10 and 15 August 2014, we returned to collect cameras and record data on site attributes and vegetation at and near each nest, using protocols similar to those used in south-coastal Alaska (e.g., Icy Bay; Kissling et al., 2015b). We photographed the nest, noted any contents, and carefully excavated the top layer of the nest to look for down, feathers, fecal matter, and eggshell fragments from previous nests. We used a combination of nest visits and photographs to determine nest fate (see Kissling and Lewis, 2015 for further details on field methods). 
We estimated mean nest density (nests $/ \mathrm{km}^{2}$, assuming perfect nest detection) and total number of nests for each ecotype in our study area, as well as their associated variances. We then calculated overall mean nest density and variance weighted by the total number of blocks and the number of sampled blocks in each stratum. We extrapolated these values to estimate the total number of nests in our study area along with the $95 \%$ confidence limits.

\section{RESULTS}

We found three active Kittlitz's Murrelet nests by flushing incubating adults from eggs. Flushing distance between observer and nest averaged $13 \mathrm{~m}$ (range $=4-17$ ). Two nests (14-01 and 14-03) were located within sampled blocks and were discovered while walking transects, and one nest (1402) was found opportunistically while in transit between blocks (Fig. 1). Two eggs were fresh ( $\leq 1$ day old), with estimated laying dates of 19 and 21 June; we estimated the other egg to be $\sim 18$ days old, with a laying date of 3 June (Table 1).

Within 24 hours after nest discovery and camera setup, we observed adult murrelets incubating eggs at all three nests. We successfully monitored nest activity and fate at two nests (14-01 and 14-02), but at nest 14-03 the camera failed three days after deployment, while an adult murrelet was still incubating the egg. All three nests failed during the egg stage (Table 1). Nest 14-01 failed because of abandonment $\sim 15$ days after laying, and the egg eventually was consumed by a red fox (Vulpes vulpes). Nest 14-02 failed as a result of red fox predation; the fox flushed both adults from the nest and then ate the egg. Owing to camera failure at nest 14-03, we cannot report the cause of failure. However, since we found no evidence of hatching (e.g., eggshell fragments) or a chick (e.g., feathers, down, fecal matter) at the nest, we conclude that the nest failed during incubation.

All nests were located within Alpine Alkaline Barrens blocks (Table 2). Mean elevation at nests was $233 \mathrm{~m}$ (range $=208-251)$, and mean slope was $19^{\circ}($ range $=7-25$; Table 2). All nests faced northward (range $=352^{\circ}-031^{\circ}$; Table 2). One nest had a moderate-sized, flat rock $(155 \mathrm{~mm}$ wide, $170 \mathrm{~mm}$ long, $45 \mathrm{~mm}$ deep) immediately uphill of the nest cup, while the other two nests were backed by small mounds (110-150 mm in height) of Dryas and lichens. Nests were composed of less than one-third silt and clay and two-thirds or more of pebbles. Within the $5 \mathrm{~m}$ nest plots, we estimated mean vegetative cover at $23 \%$ (range $=10 \%-40 \%$ ). Vegetation was primarily Dryas, but also included small amounts of lichens and grasses (Table 2).

We estimated overall mean nest density to be 0.80 nests/ $\mathrm{km}^{2}(\mathrm{SE}=0.52)$ and the total number of nests in our study area to be $18.6(95 \%$ confidence interval $=17.4-19.8$; Table 3). Nest density was 1.45 nests $/ \mathrm{km}^{2}(\mathrm{SE}=1.00)$ in Alpine Alkaline Barrens and 0.00 in Alpine Dryas Dwarf Shrub, where we did not locate any nests (Table 3). Apparent nesting success was zero.

\section{DISCUSSION}

Our results suggest that Kittlitz's Murrelets regularly nest in this vast region, more so than was indicated by previous opportunistic and occasional nest discoveries. Several authors have predicted that this vast region contains a substantial amount of potential nesting habitat for Kittlitz's Murrelets (e.g., Day et al., 2011). Felis et al. (in press) estimated that more than $27000 \mathrm{~km}^{2}$, or $11 \%$ of the total land area, serves as potential nesting habitat for this species, more than is found in any other region in Alaska. Yet our study was the first to estimate nest density and success in northern Alaska.

Our estimate of Kittlitz's Murrelet nest density ( 0.80 nests $/ \mathrm{km}^{2}$ ) in alpine ecotypes was higher than the only other estimate available across the species' range. On Kodiak Island, Lawonn (2012) searched seemingly suitable and accessible terrain thoroughly and estimated a density of 0.12 nests $/ \mathrm{km}^{2}$. However, because researchers on Kodiak Island did not use a sampling design when searching for nests, these two estimates are not directly comparable. This same limitation applies to efforts on Agattu and Adak Islands in the Aleutian Archipelago, where researchers searched and discovered nests opportunistically, although we are not aware of a nest density estimate for this region (Kaler et al., 2009; Kenney and Kaler, 2013; USFWS, 2013). Our study was limited to a small area, relied on a small sample size of surveyed blocks (especially in Alpine Dryas Dwarf Shrub), and was conducted for one year only, but our approach and results are statistically valid and repeatable. We urge researchers to use sampling designs when searching for Kittlitz's Murrelet nests to generate unbiased estimates of nest density and success and permit valid comparisons and inference within and across study sites.

Although Kittlitz's Murrelets attempted to nest in our study area, no nest was successful. This finding underscores that, although this species nests in northern Alaska, nesting success appears to be low; in fact, successful reproduction in the region has yet to be documented. All nests monitored during our study failed during incubation, suggesting that, if there is a bottleneck to successful reproduction and recruitment, it probably is occurring at that stage. Of the two nests with known cause of failure, one was abandoned (14-01) and one was depredated (14-02). Brachyramphus murrelet parents abandon nests (or appear to) for many reasons, including disturbance (e.g., Hébert et al., 2006), lack of high-quality prey (e.g., Peery et al., 2004; Janssen et al., 2009), or fatality away from the nest (e.g., Kissling et al., 2015a). Owing to the solitary and remote nesting habits of Kittlitz's Murrelet, it may be difficult to diagnose nest abandonment with reasonable certainty, especially across study areas and the species range. It is worth noting here that at nest 14-02, only one photograph included a red fox, indicating that depredation events are likely to be brief; cameras set to record at one-minute or longer intervals may fail to record these events, leading the researcher to conclude incorrectly that the nest was abandoned. 
TABLE 1. Chronology and cause of failure for Kittlitz's Murrelet nests found and monitored in the Kakagrak Hills, Cape Krusenstern National Monument, northwestern Alaska, in summer 2014.

\begin{tabular}{|c|c|c|c|c|c|c|c|}
\hline \multirow[b]{2}{*}{ Nest identifier } & \multirow[b]{2}{*}{ Date found } & \multirow[b]{2}{*}{ Egg mass (g) } & \multicolumn{2}{|c|}{ Egg dimensions (mm) } & \multirow{2}{*}{$\begin{array}{l}\text { Estimated } \\
\text { laying date }\end{array}$} & \multirow{2}{*}{$\begin{array}{l}\text { Last date nest known } \\
\text { to be active }\end{array}$} & \multirow[b]{2}{*}{ Cause of failure } \\
\hline & & & Length & Width & & & \\
\hline 14-01 & 20 June & 51.6 & 60.8 & 39.4 & 19 June & 5 July & Abandonment \\
\hline $14-02$ & 21 June & 44.9 & 57.8 & 39.5 & 3 June & 23 June & Predation by red fox \\
\hline $14-03$ & 22 June & 47.2 & 59.1 & 37.8 & 21 June & 25 June $^{1}$ & Unknown \\
\hline
\end{tabular}

${ }^{1}$ Camera failed while nest was active.

TABLE 2. Site and habitat attributes within $5 \mathrm{~m}$ plots around known Kittlitz's Murrelet nests in the Kakagrak Hills, Cape Krusenstern National Monument, northwestern Alaska.

\begin{tabular}{|c|c|c|c|c|c|c|c|}
\hline Nest identifier & Ecotype & $\begin{array}{l}\text { Elevation } \\
\text { (m) }\end{array}$ & $\begin{array}{l}\text { Slope } \\
\left({ }^{\circ}\right)\end{array}$ & $\begin{array}{c}\text { Aspect } \\
\left({ }^{\circ}\right)\end{array}$ & $\begin{array}{l}\text { Vegetative } \\
\text { cover }(\%)\end{array}$ & $\begin{array}{l}\text { Linear distance } \\
\text { to ocean }(\mathrm{km})\end{array}$ & Fate \\
\hline 2010 Nest & Alpine Dryas Dwarf Shrub & 157 & 10 & 208 & 45 & 3.4 & Failed - inferred \\
\hline 2013 Nest & Alpine Alkaline Barrens & 153 & 24 & 284 & 50 & 4.1 & Failed - confirmed \\
\hline $14-01$ & Alpine Alkaline Barrens & 251 & 25 & 005 & 40 & 6.0 & Failed - confirmed \\
\hline $14-02$ & Alpine Alkaline Barrens & 240 & 7 & 031 & 10 & 4.7 & Failed - confirmed \\
\hline $14-03$ & Alpine Alkaline Barrens & 208 & 24 & 352 & 20 & 4.8 & Failed - confirmed \\
\hline
\end{tabular}

TABLE 3. Sampling effort and estimated Kittlitz's Murrelet nest density by ecotype, Kakagrak Hills, Cape Krusenstern National Monument, northwestern Alaska, summer 2014.

\begin{tabular}{|c|c|c|c|}
\hline & \multicolumn{2}{|c|}{ Ecotype } & \multirow[b]{2}{*}{ Both strata } \\
\hline & Alpine Alkaline Barrens & Alpine Dryas Dwarf Shrub & \\
\hline Total number of blocks in study area & 205 & 169 & 374 \\
\hline Number of blocks sampled & 22 & 6 & 28 \\
\hline Number of nests found & $2^{1}$ & 0 & 2 \\
\hline Mean nest density per $\mathrm{km}^{2}$ (SE) & $1.45(1.00)$ & 0.00 & $0.80(0.52)$ \\
\hline Estimate of total number of nests in study area (SE) & $18.6(12.9)$ & 0.0 & $18.6(0.6)$ \\
\hline
\end{tabular}

${ }^{1}$ We found a third nest opportunistically during transit, but did not include it in the density estimates.

Our results, along with others (e.g., Lawonn, 2012), indicate that nest predation plays a significant role in limiting the productivity of Kittlitz's Murrelets. In the three nests we monitored, only one failure was definitively due to predation, but circumstantial evidence from the other two nests suggests that predators also contributed to their failure. At nest 14-01, the incubating adult fled from the nest during mid-day when a brown bear (Ursus arctos) approached. Although the bear did not find and eat the egg, neither adult murrelet returned to the nest, and the egg eventually was discovered and eaten by a red fox. Similarly, nests $14-02$ and 14-03 were situated only $200 \mathrm{~m}$ away from one another, and both were located on the same mountain as an active red fox den that was $\sim 1.4 \mathrm{~km}$ away; on several occasions, we observed an adult red fox foraging on the mountain. It is possible that the camera equipment may have attracted predators such as foxes to the nest area and thereby increased the likelihood of nest predation, but we do not believe this was the case. In reviewing photographs taken at nest 14-01, we observed a fox near the nest, but it seemed to be unaware of the nest and did not disturb the incubating murrelet. In addition, Lawonn (2012) did not detect differences in nesting success between Kittlitz's Murrelets nests with and without camera surveillance, and other studies reported reduced predation rates at nests with camera equipment (see Richardson et al., 2009). Nevertheless, we acknowledge a possible bias in our results due to the presence of cameras at the nest.

We successfully searched for Kittlitz's Murrelet nests using a stratified random sampling design with a block as a sampling unit, allowing for unbiased estimation of nest density and nesting success. We recommend reducing block size from $250 \times 250 \mathrm{~m}$ to $200 \times 200 \mathrm{~m}$ in the future for two reasons: (1) to avoid inaccuracies in ecotype assignment and (2) to space line transects within the block closer together. A shorter distance between transects would reduce possible violation of the assumption of perfect nest detection. Alternatively, we suggest estimating nest detection probability directly by surveying transects multiple times, using an experimental approach with fake eggs, or employing any other viable method. Otherwise, our design and protocol were practical, simple to implement, and effective. For future studies aiming to estimate nest density and nesting success, we recommend using a similar sampling design to generate unbiased estimates and to allow for reliable comparison across years and study sites. Without an appropriate sampling design for such studies, inference of results is both weak and limited in scope. 
Over the last decade, researchers have substantially advanced our knowledge of the natural history of Kittlitz's Murrelet, yet we still lack useful and reliable information for assessing the status of the species into the future. Our results presented here emphasize the need for broadscale study of vital rates and the factors affecting them to quantify the marine and terrestrial habitat requirements of Kittlitz's Murrelets across their range. We can then develop targeted conservation measures to facilitate the persistence of this species.

\section{ACKNOWLEDGEMENTS}

We volunteered to complete this work with partial funding from the Alaska Geographic Research Fellowship Program. We are grateful to both Alaska Geographic and the National Park Service for the opportunity and to Luke DeCicco, Nick Hajdukovich, and Jerry Rounds for sharing their nest discoveries with us, which prompted our study. We thank Marci Johnson (National Park Service), Tina Moran (U.S. Fish and Wildlife Service), and Eric Sieh (Alaska Backcountry Flying Services) in Kotzebue for logistical support and encouragement, and Paul Lukacs (University of Montana) for statistical help. We appreciate constructive suggestions and comments from Bob Day and two anonymous reviewers that greatly improved our manuscript.

\section{REFERENCES}

Artukhin, Y.B., Vyatkin, P.S., Andreev, A.V., Konyukhov, N.B., and Van Pelt, T.I. 2011. Status of the Kittlitz's Murrelet Brachyramphus brevirostris in Russia. Marine Ornithology 39:23-33.

Day, R.H. 1996. Nesting phenology of Kittlitz's Murrelet. The Condor 98:433-437.

http://dx.doi.org/10.2307/1369165

Day, R.H., and Nigro, D.A. 2004. Is the Kittlitz's Murrelet exhibiting reproductive problems in Prince William Sound, Alaska? Waterbirds 27(1):89-95.

http://dx.doi.org/10.1675/1524-4695(2004)027[0089:ITKMER ]2.0.CO;2

Day, R.H., Kuletz, K.J., and Nigro, D.A. 1999. Kittlitz's Murrelet (Brachyramphus brevirostris). In: Poole, A., and Gill, F., eds. The birds of North America. Washington, D.C.: Academy of Natural Sciences; Philadelphia, Pennsylvania: American Ornithologists' Union.

Day, R.H., Gall, A.E., Prichard, A.K., Divoky, G.J., and Rojek, N.A. 2011. The status and distribution of Kittlitz's Murrelet Brachyramphus brevirostris in northern Alaska. Marine Ornithology 39:53-63.

Felis, J.J., Kissling, M.L., Kaler, R.S.A., Kenney, L., and Lawonn, M.J. In press. Identifying Kittlitz's Murrelet nesting habitat in North America at the landscape scale. Journal of Fish and Wildlife Management.
Hébert, P.N., Golightly, R.T., and Orthmeyer, D.L. 2006. Evaluation of human-caused disturbance on the breeding success of Marbled Murrelets (Brachyramphus marmoratus) in Redwood National and State Parks, California. In: Hébert, P.N., and Golightly, R.T. Movements, nesting, and response to anthropogenic disturbance of Marbled Murrelets (Brachyramphus marmoratus) in Redwood National and State Parks, California. Arcata, California: Department of Wildlife, Humboldt State University. 1-68.

Janssen, M.H., Arcese, P., Kyser, T.K., Bertram, D.F., McFarlane Tranquilla, L., Williams, T.D., and Norris, D.R. 2009. Prebreeding diet, condition and timing of breeding in a threatened seabird, the Marbled Murrelet Brachyramphus marmoratus. Marine Ornithology 37:33-40.

Jorgenson, M.T., Roth, J.E., Miller, P.F., Macander, M.J., Duffy, M.S., Wells, A.F., Frost, G.V., and Pullman, E.R. 2009. An ecological land survey and landcover map of the Arctic Network. Natural Resource Technical Report NPS/ARCN/ NRTR - 2009/270. Fort Collins, Colorado: National Park Service.

Kaler, R.S.A., Kenney, L.A., and Piatt, J.F. 2008. Breeding biology of Kittlitz's Murrelets at Agattu Island, Alaska in 2008: Progress report. AMNWR 08/17. Homer, Alaska: U.S. Fish and Wildlife Service.

Kaler, R.S.A., Kenney, L.A., and Sandercock, B.K. 2009. Breeding ecology of Kittlitz's Murrelets at Agattu Island, Aleutian Archipelago, Alaska. Waterbirds 32(3):363-373. http://dx.doi.org/10.1675/063.032.0301

Kenney, L.A., and Kaler, R.S.A. 2013. Identifying nesting habitat of Kittlitz's Murrelets Brachyramphus brevirostris: Old nests lead to a new breeding record. Marine Ornithology 41:73-74.

Kirchhoff, M.D., Lindell, J.R., and Hodges, J.I. 2014. From critically endangered to least concern?-A revised population trend for the Kittlitz's Murrelet in Glacier Bay, Alaska. The Condor 116(1):24-34. http://dx.doi.org/10.1650/CONDOR-13-123.1

Kissling, M.L., and Lewis, S.B. 2015. Nesting activity of the Kittlitz's Murrelet in the Kakagrak Hills, Cape Krusenstern National Monument, northwestern Alaska, summer 2014. Unpubl. ms. Available at 947 Goldbelt Ave., Juneau, Alaska 99801, USA.

Kissling, M.L., Lukacs, P.M., Gende, S.M., and Lewis, S.B. 2015a. Multi-state mark-recapture model to estimate survival of a dispersed-nesting seabird, the Kittlitz's murrelet. Journal of Wildlife Management 79(1):20-30.

http://dx.doi.org/10.1002/jwmg.811

Kissling, M.L., Gende, S.M., Lewis, S.B., and Lukacs, P.M. 2015b. Reproductive performance of Kittlitz's Murrelet in a glacially influenced landscape, Icy Bay, Alaska. The Condor 117:237-248. http://dx.doi.org/10.1650/CONDOR-14-67.1

Kuletz, K.J., Nations, C.S., Manly, B., Allyn, A., Irons, D.B., and McKnight, A. 2011. Distribution, abundance and population trends of the Kittlitz's Murrelet Brachyramphus brevirostris in Prince William Sound, Alaska. Marine Ornithology 39:97-109. 
Lawonn, M.J. 2012. Breeding ecology and nest site selection of Kittlitz's Murrelets on Kodiak Island, Alaska. MSc thesis, Oregon State University, Corvallis, Oregon.

Madison, E.N., Piatt, J.F., Arimitsu, M., Romano, M.D., Van Pelt, T.I., Nelson, S.K., Williams, J.C., and DeGange, A.R. 2011. Status and distribution of the Kittlitz's Murrelet Brachyramphus brevirostris along the Alaska Peninsula and Kodiak and Aleutian Islands, Alaska. Marine Ornithology 39(1):111-122.

National Weather Service. 2014. Alaska climate database. http://www.arh.noaa.gov/cliMap/akClimate.php

Peery, M.Z., Beissinger, S.R., Newman, S.H., Burkett, E.B., and Williams, T.D. 2004. Applying the declining population paradigm: Diagnosing causes of poor reproduction in the Marbled Murrelet. Conservation Biology 18(4):1088-1098.

http://dx.doi.org/10.1111/j.1523-1739.2004.00134.x
Piatt, J.F., Arimitsu, M., Drew, G., Madison, E.N., Bodkin, J., and Romano, M.D. 2011. Status and trend of the Kittlitz's Murrelet Brachyramphus brevirostris in Glacier Bay, Alaska. Marine Ornithology 39:65-75.

Richardson, T.W., Gardali, T., and Jenkins, S.H. 2009. Review and meta-analysis of camera effects on avian nest success. Journal of Wildlife Management 73(2):287-293. http://dx.doi.org/10.2193/2007-566

USFWS (U.S. Fish and Wildlife Service). 2013. 12-month finding on a petition to list Kittlitz's Murrelet as an endangered or threatened species. Federal Register 78(192):61764-61801. 